\title{
Induction of Pathogenesis-Related Proteins of Group 1 by Systemic Virus Infections of Nicotiana tabacum L.*
}

\author{
by \\ Cornelia Röbring, \\ Herrmann-Meyer-Str. 61, \\ 04207 Leiprig, \\ Germany.
}

\section{SUMMARY}

The induction of acid pathogenesis-related proteins (PRproteins) of group 1 (PR-1) by systemic virus infections of tobacco plants was investigated during a time period between 3 and 19 days after inoculation. Each leaf position was investigated separately. The PR proteins were detected electrophoretically and, in addition, virus protein was detected by Enzyme Linked Immunosorbent Assay (ELISA). Potato virus X (PVX) and potato virus $\mathrm{Y}$ (PVY) were found to highly induce PR proteins in $N$. tabacum L. „Samsun NN“. The same results were obtained when PVX was investigated in N. tabacum L. "Samsun“. The accumulation started later and took place more slowly than during hypersensitive host reaction (HR) of „Samsun NN" to tobacco mosaic virus (TMV). A correlation was found between the accumulation of PR proteins and the accumulation of the virus in the same leaf. Cucumber mosaic virus (CMV) was less effective in PR protein induction than PVX and PVY. Consequently it could be demonstrated that $\mathrm{PR}$ proteins do not only appear due to hypersensitive host reactions but also during systemic virus infections.

\section{ZUSAMMENFASSUNG}

Es wurde das Auftreten von sauren, pathogenesis-related (PR)-Proteinen der Gruppe 1 (PR-1) infolge systemischer Virusinfektionen bei Tabak im Zeitraum von 3 bis 19

*Received: 9th March 1998 - accepted: 23rd June 1998
Tagen nach der Inokulation untersucht. Jede Blattetage wurde separat geprüft. Die PR-Proteine wurden elektrophoretisch nachgewiesen. Außerdem wurde mittels ELISA die Akkumulation der Virusproteine verfolgt. Die PR-Proteine wurden sowohl durch das Kartoffel-X-Virus (PVX) als auch durch das Kartoffel-Y-Virus (PVY) in N. tabacum L. "Samsun NN“ in starkem Maße induziert. Auch die Sorte "Samsun“ zeigte nach PVX-Infektion diesen Effekt. Die Anreicherung begann später und erfolgte langsamer als bei hypersensitiver Wirtsreaktion (HR) von „Samsun NN“-Tabak gegenüber dem Tabakmosaikvirus (TMV). Zwischen der Akkumulation der PRProteine und der Anreicherung des Virus in der entsprechenden Blattetage konnte eine zeitliche Korrelation festgestellt werde. Das Gurkenmosaikvirus (CMV) induzierte PR-Proteine nur in deutlich geringerem Umfang als PVX und PVY. Somit konnte gezeigt werden, dass PR-Proteine nicht nur bei hypersensitiven Wirtsreaktionen auftreten, sondern auch bei systemischen Virusinfektionen.

\section{RESUME}

L'auteur a examiné pendant une période de trois à dixneuf jours après inoculation, l'induction de protéines acides de type PR-1 dans les feuilles de tabac attaquées par les infections systémiques à virus. Chaque nœud a été examiné séparément. Les protéines de type PR-1 ont été décelées à l'aide de l'électrophorèse. En outre, l'accumulation des protéines des virus a été dosée grâce au test ELISA. Les protéines de type PR-1 ont fortement été induites chez N. tabacum L. Samsun NN' par le virus X et 
par le virus Y de la pomme de terre (PVX et PVY). L'induction de ces protéines par PVX a également pu être démontrée chez N. tabacum ,Samsun'. Chez N. tabacum ,Samsun', l'accumulation des protéines de type PR-1 s'est manifestée ultérieurement et plus lentement que dans le cas d'une réponse hypersensible (HR) au virus de la mosaïque du tabac (TMV) chez N. tabacum ,Samsun NN‘. Une corrélation en fonction du temps entre l'accumulation de protéines de type PR-1 et l'accumulation du virus dans les feuilles correspondantes a pu être observée. L'induction de protéines de type PR-1 par le virus de la mosaïque de la concombre (CMV) était sensiblement plus faible que l'induction de ces protéines par PVX et PVY. Ainsi l'auteur a pu démontrer que l'induction de protéines de type PR-1 ne se manifeste non seulement dans le cas de réponses hypersensitives mais aussi dans le cas d'infections systémiques à virus.

\section{INTRODUCTION}

If a plant is infected by a virus there are two possible reactions: a) the virus spreads and replicates in the plant (systemic infection) or b) an active defense mechanism of the plant called hypersensitive host reaction localizes the virus to the point of entrance and a small surrounding area of cells. Systemic infections lead to more or less visible symptoms which are typical for the direct combination of virus and host. Hypersensitive host reactions are accompanied by the formation of local necroses (local lesions) some days after inoculation, numerous biochemical changes (1), accumulation of PR proteins (for review see 2,3 ), and in most cases by the development of a systemic acquired resistance. After a secondary infection of primarily not infected leafs this resistance leads to the formation of less and/or smaller local lesions compared to not infected plants $(4,5)$. The intensity of systemic acquired resistance is in correlation with the expression of the genes of PR proteins (6).

Some PR proteins are ascribed a role in defense against phytopathogenic fungi. PR-1a and PR-1b as well as PR proteins of group 5 show antifungal effects $(7,8)$. PR proteins of group 2 are -1,3-glucanases and the proteins of group 3 are chitinases. MAUCH and STAEHELIN discuss an interesting model for the role of these two groups of PR proteins in the defense against fungi (9).

Tobacco species carrying the $N$-gene (e.g. N. tabacum L. "Samsun NN“) react to an infection by TMV with a hypersensitive response and the accumulation of acidic PR proteins $(10,11)$ which are divided into five groups (12). This incompatible virus-host-system has been intensively reported in the literature in contrast to the correlation between systemic virus infections and PR proteins. N. tabacum L. „Samsun“ reacts systemically to TMV and does not accumulate PR proteins due to the infection (10). On the contrary, VAN LOON found a small amount of PR proteins after systemic infection of N. tabacum L. „Samsun “ and „Samsun NN“ with CMV and PVY, respectively (13). In N. tabacum L. „Xanthi-nc“ PR proteins were found by KASSANIS et al. due to systemic infections by different viruses (14). This paper focuses on systemic acquired resistance, therefore only a few data concerning PR proteins are given.

Reviews published in recent years have not considered the problem of accumulation of PR proteins after systemic virus infections (3), or only mentioned that N. tabacum L. "Samsun“ does not synthesize any of them due to infection by $\operatorname{TMV}(15,16)$. Only earlier reviews cited the work of VAN LOON and VAN KAMMEN $(17,18,19)$.

In this paper which is based on a thesis at the University of Leipzig, Institute of Botany, Department of General Botany (20), the question whether acidic PR proteins are accumulated due to systemic virus infections was re-investigated. N. tabacum L. „Samsun NN“ was investigated after infection with PVX, PVY or CMV. The PR protein pattern was documented electrophoretically during a period of time between 3 and 19 days post inoculation (d p. i.). Each leaf was examined separately. In addition to this, the accumulation of the virus in every leaf was determined by ELISA.

\section{MATERIALS AND METHODS}

Nicotiana tabacum L. „Samsun NN“ plants were infected with PVX, PVY or CMV when they had four fullyexpanded leaves. The second oldest leaf was inoculated with infectious plant sap after applying carborundum powder. The control plants were inoculated with distilled water.

Ten plants were used for each kind of infection and for each investigation time. The plants were investigated 3, 6, 10, 14 and $19 \mathrm{~d}$ p. i. The leaves were harvested separately from each stalk position. The corresponding leaves of the ten plants were combined and used for determination of virus content by ELISA and electrophoretic separation of PR proteins, respectively.

Virus accumulation was determined by ELISA (21) using test kits by LÖWE (Munich, Germany). The leaves were crushed with a plant crusher, the sap was centrifuged for $10 \mathrm{~min}$ at $2000 \mathrm{~g}$ and diluted $1: 1000$ (PVX, PVY) or $1: 100$ (CMV) with $2 \%$ polyvinylpyrrolidone $\mathrm{K} 25$ and $0.2 \%$ albumin from bovine serum in phosphate buffer $\mathrm{pH} 7.3\left(8 \mathrm{mM} \mathrm{Na}_{2} \mathrm{HPO}_{4}\right.$ $\times 12 \mathrm{H}_{2} \mathrm{O}, 1.5 \mathrm{mM} \mathrm{KH}_{2} \mathrm{PO}_{4}, 137 \mathrm{mM} \mathrm{NaCl}, 2.7 \mathrm{mM}$ $\mathrm{KCl}, 3 \mathrm{mM} \mathrm{NaN}_{3}$ ). All samples were measured three times. 
For electrophoretic separation of PR proteins intercellular fluid extracts of the leaves were used (22). $20 \mathrm{~mL}$ per gram cold $\left(4^{\circ} \mathrm{C}\right)$ citrate buffer $\mathrm{pH} 2.8$ $\left(30 \mathrm{mM} \mathrm{Na}_{2} \mathrm{HPO}_{4} \times 12 \mathrm{H}_{2} \mathrm{O}, 80 \mathrm{mM}\right.$ citric acid, $6 \mathrm{mM}$ ascorbic acid, $14 \mathrm{mM}$ 2-mercaptoethanol) were poured over half leaves. The glass containers were evacuated in an ice bath for $5 \mathrm{~min}$, and left to rest for $10 \mathrm{~min}$. The buffer was poured off and the leaves were dried on cellulose and put on a piece of gauze into a conical centrifugal tube-top. After $10 \mathrm{~min}$ of centrifugation at $2000 \mathrm{~g}$ the sap at the bottom of the tube was frozen at $-20^{\circ} \mathrm{C}$ and used for electrophoresis (23).

Electrophoresis was performed with a basic native buffer system (24) in $12 \%$ gels with a size of $150 \times 100 \times 1 \mathrm{~mm} .10 \mu \mathrm{L}$ glycerol and $5 \mu \mathrm{L} 0.1 \%$ bromphenol blue were added to $100 \mu \mathrm{L}$ of intercellular fluid extract. From this mixture $20 \mu \mathrm{L}$ were used per lane. The gels were stained with silver (25). The identification of PR proteins was performed by comparing the electrophoretic pattern as well as the molecular weights of the proteins with the literature $(12,26)$. Molecular weights were determined according to HEDRICK and SMITH (27) using four native gels with acrylamide concentrations of $10,12,14$ and $16 \%$, respectively. Only the PR proteins of group 1 could be clearly identified with these methods, therefore this study focuses on them.

\section{RESULTS}

It was found that N. tabacum L. "Samsun NN" reacts to a systemic virus infection with PVX, PVY or CMV with an accumulation of acidic $P R$ proteins $1 a, b$ and c. They were seen in the electrophoretic pattern for the first time $6 \mathrm{~d}$ p. i. in case of PVX infection (Figure 1) and $10 \mathrm{~d}$ p. i. in case of PVY or CMV infection (Figure 2). They first appeared in the inoculated leaf, followed by the youngest leaves which were growing during infection time. The accumulation of PR proteins in leafs whose stalk position was above the inoculated leaf, which was already fully-expanded at the moment of inoculation, appeared later and/or to a smaller degree compared with the new growing leaves. In addition, the virus replication started later and was slower. The leaves growing below the inoculated leaf did not accumulate significant amounts of PR proteins. The amount of virus protein accumulated in these leaves were also small or undetectable. In the case of PVX, virus protein could be detected by ELISA $3 \mathrm{~d}$ p. i. in the inoculated leaf. At this time no PR protein was found in any of the leaves. Three days later the virus content was increased in the inoculated leaf, but not in the other leaves. In the inoculated leaf a small amount of PR-1a and b was found. Four days later, all leaves with a high level of virus protein (inoculated leaf and the leaves inserted two or three stalk positions higher) had accumulated PR-1a and $b$ and, to a smaller amount, 1c. The accumulation of PR-1c after systemic PVX infection was much lower than that due to the hypersensitive reaction of „Samsun NN" tobacco to TMV infection, which was used as reference (Figure 1). This remained unchanged up to $19 \mathrm{~d}$ p. i. All growing leaves had a high content of virus protein as well as of PR- $1 \mathrm{a}$ and $\mathrm{b}$ and $\mathrm{a}$ smaller one of $1 \mathrm{c}$. The virus spread and the accumulation of PR proteins in N. tabacum L. "Samsun“ was similar (for detailed information see 20).

The induction of PR-proteins after infection with PVY was similar to that after infection with PVX, but appeared a little later. PR-1a and b could not be detected in the electrophoretic pattern $6 \mathrm{~d}$ p. i. At this time, the virus content of the inoculated leaf was still small. $10 \mathrm{~d}$ p. i. PR-1a, b and c had been accumulated to a high amount in the inoculated leaf and two leaf positions higher. The youngest leaf had accumulated - in contrast to PVX infection - only a small amount of PR proteins. However, the concentration of virus protein was higher in this leaf than in the others. Up to $19 \mathrm{~d}$ p. i. all leaves inserted higher than the inoculated one accumulated a significant amount of PR- $1 \mathrm{a}, \mathrm{b}$ and $\mathrm{c}$ with a decreasing gradient up to the youngest leaves.

CMV-infected "Samsun NN“ plants accumulated PR$1 \mathrm{a}, \mathrm{b}$ and $\mathrm{c}$ to high amounts only in the inoculated leaf. They appeared for the first time $10 \mathrm{~d}$ p. i. The virus content did not reach a high level in any of the leaves up to $10 \mathrm{~d}$ p. i. and remained maximum in the inoculated leaf.

\section{DISCUSSION}

It was found that N. tabacum L. "Samsun NN" reacts to systemic virus infections with PVX, PVY and CMV, respectively, with an accumulation of $\mathrm{PR}$ proteins $1 \mathrm{a}$, $\mathrm{b}$ and $\mathrm{c}$. They occurred later than during a hypersensitive reaction. Between 5 and 7 days after inoculation they are accumulated at a high level during hypersensitive reaction. During systemic infection they were found in most cases at $6 \mathrm{~d}$ p. i. only in the inoculated leaf. The maximum amount was reached after $14 \mathrm{~d}$ p. i. and remained stable up to the end of investigation period $19 \mathrm{~d}$ p. i.

The accumulation of $P R$ proteins in the individual leaves correlated with the accumulation of virus protein in these leaves. They first appeared in the inoculated leaf, followed by the new growing ones and later by the leaves inserted between them. Most of the viruses spread through the phloem in accordance with the source sink relations $(28,29)$. The ELISA results clearly show this phenomenon. The PR protein bands appeared in the electrophoretic 

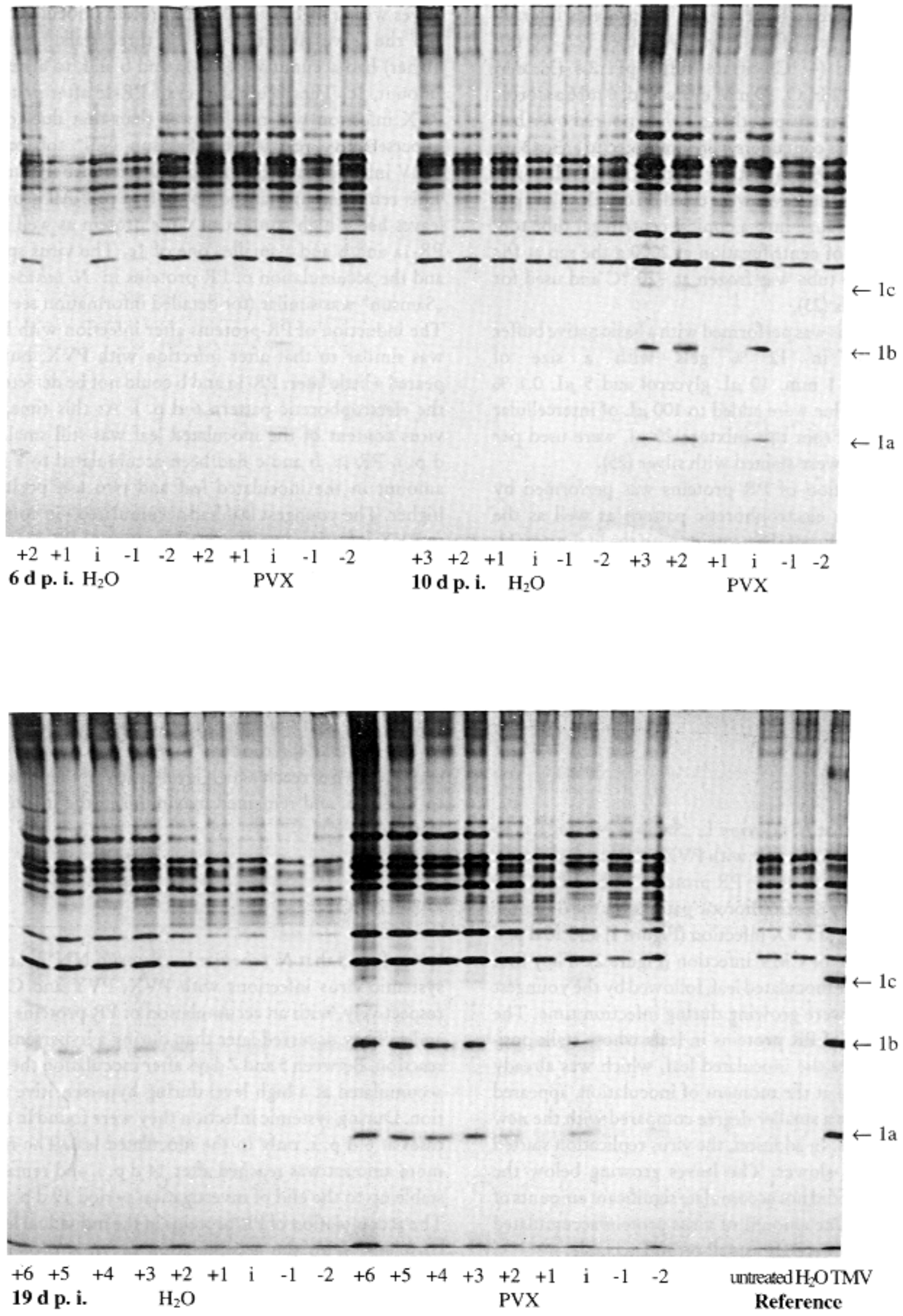

Figure 1.

Accumulation of PR proteins of group 1 due to systemic infection of Nicotiana tabacum L. ,Samsun NN' with PVX in dependence of leaf insertion at different times after inoculation ( $i=$ inoculated leaf; $+1,+2,+3,+4,+5,+6=$ first, second, third, fourth, fifth, sixth leaf above the inoculated one; $-1,-2=$ first and second leaf below the inoculated one). 

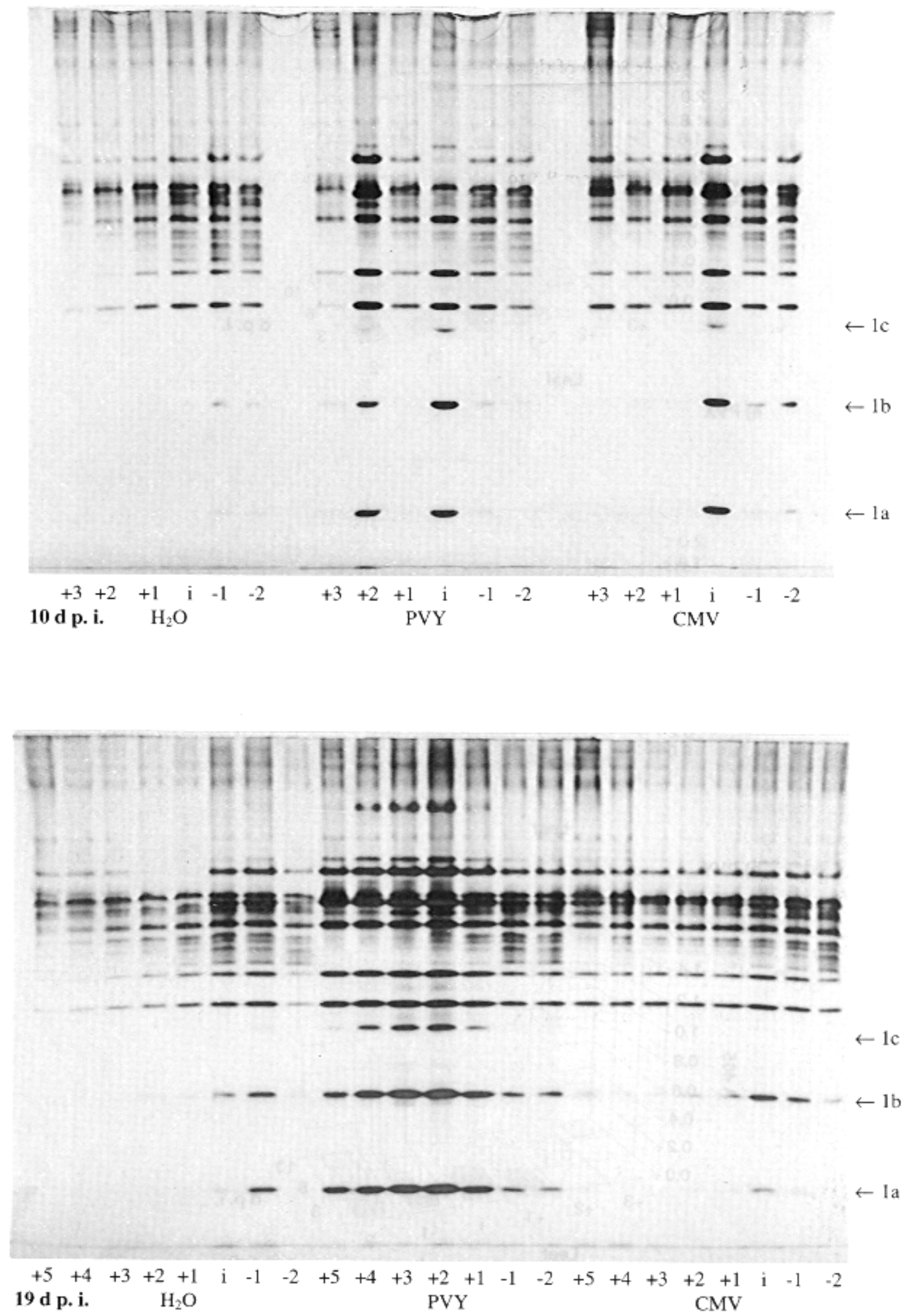

Figure 2.

Accumulation of PR proteins of group 1 due to systemic infection of Nicotiana tabacum L. ,Samsun NN' with PVY or CMV in dependence of leaf insertion at different times after inoculation ( $\mathrm{i}=$ inoculated leaf; $+1,+2,+3,+4,+5=$ first, second, third, fourth, fifth leaf above the inoculated one; $-1,-2$ = first and second leaf below the inoculated one). 


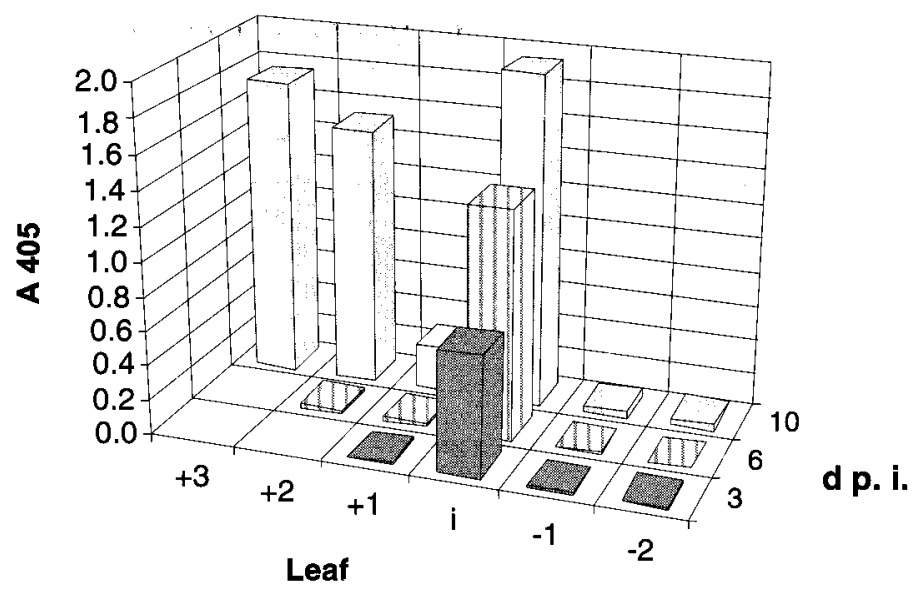

a) PVX

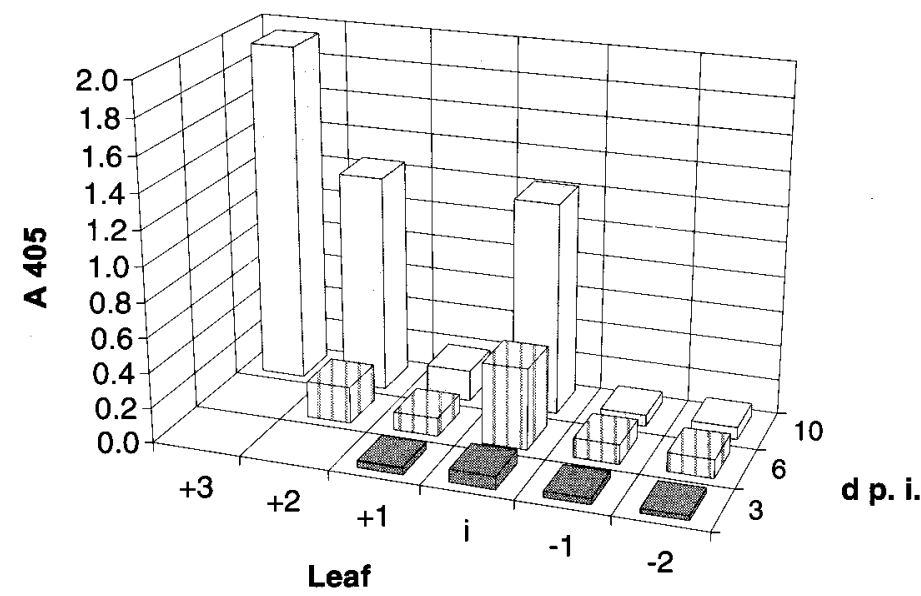

b) PVY

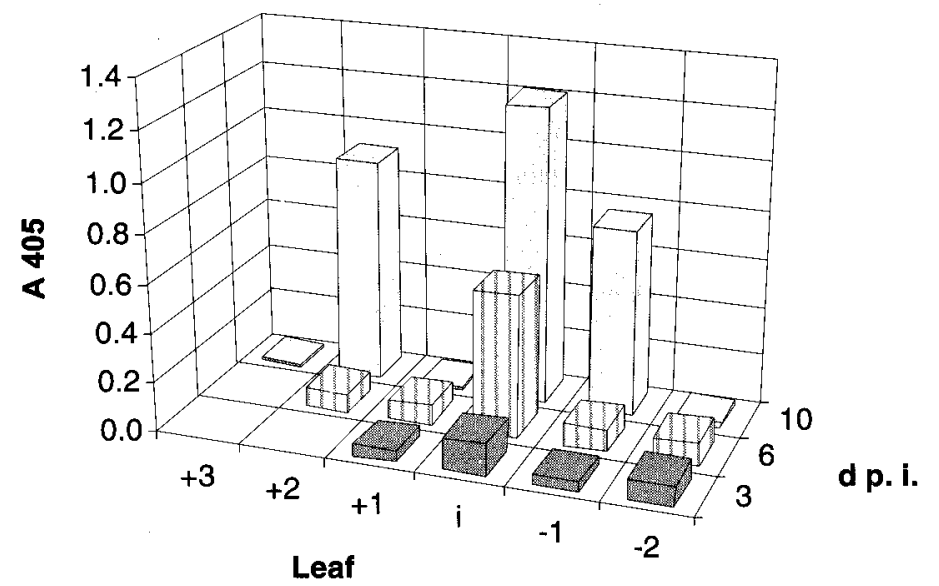

c) CMV

Figure 3.

Accumulation of virus protein in Nicotiana tabacum L. ,Samsun NN' detected by ELISA in dependence of time after inoculation ( $d$ p. I.) and leaf insertion ( $i=$ inoculated leaf; $+1,+2,+3=$ first, second, third leaf above the inoculated one; $-1,-2=$ first and second leaf below the inoculated one). 
pattern later than the detection of virus protein by ELISA. Nevertheless, because of the different sensitivity of these two methods it is not possible to conclude that the virus first accumulates in a leaf and than induces the synthesis of PR proteins. It is also possible that the virus replication in the inoculated leaf induces a signal that is transported through the phloem or that both processes are closely connected in such a way, that $P R$ protein accumulation is an effect of early aging in leaves with high virus content. The old leaves lower inserted than the inoculated ones accumulated PR- $1 \mathrm{a}, \mathrm{b}$ and $\mathrm{c}$ independently of an infection. The appearance of PR proteins in healthy plants is often described in the literature $(30,31,32$, 33, 34). GRÜNER and PFITZNER observed a gradient of PR-1 in healthy tobacco plants with maximum amount in the oldest leaves (35). The authors suggest that these proteins play a role in late phases of plant development.

The accumulation of $\mathrm{PR}$ proteins during systemic infections is not linked to the N-gene. N. tabacum L. „Samsun“ as well was investigated concerning PVXinfection and the results were the same as for "Samsun NN“ (for data see 20). This is in agreement with the results of VAN LOON (10) who found PR-1a, $b$ and c in "Samsun NN" as well as in "Samsun“ after infection with CMV and particularly after infection with PVY, but in all cases the concentration was much lower than after TMV infection of "Samsun

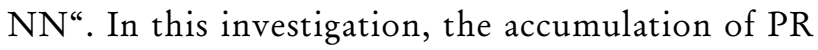
proteins induced by CMV-infection was smaller than that after infection with PVX and PVY, in addition, the $\mathrm{PR}$ proteins were only accumulated in the inoculated leaves. For PVX and PVY, all growing leaves showed high amounts of PR proteins of group 1 and, concerning PR-1a and b, the intensity of electrophoretic pattern $19 \mathrm{~d}$ p. i. was as high as after infection of „Samsun NN“with TMV 5 d p .i. However, PR-1c was weakly accumulated. The inoculation of already PVX-infected ,Samsun NN', that means the combination of a systemic infection with an incompatible reaction both inducing $P R$ proteins, did not lead to synergistic effects. The electrophoretic bands of PR$1 \mathrm{a}$ and $\mathrm{b}$ were not more intensive than that of control plants only infected with PVX or TMV, respectively. Only PR-1c was more strongly induced by TMV than by PVX (for data see 20). The occurrence of PR proteins during systemic virus infections suggests that there cannot be a direct link between the synthesis of PR proteins on the one hand and of the phenomenon of localization and necrobiosis on the other hand. Therefore it is not surprising that a constitutive expression of one or more PR proteins in transgenic tobacco has no effect on systemic virus infections or hypersensitive host reactions against viruses $(35,36)$. Therefore, breeding of resistant plants by this way may not be possible.

\section{REFERENCES}

1. Van Loon, L.C.: Mechanisms of resistance in virusinfected plants; in: The dynamics of host defense, edited by J.A. Bailey and B.J. Deverall, Academic Press Australia, Sydney, 1983, pp. 123-190.

2. Redolfi,P.: Occurrence of pathogenesis-related (b) and similar proteins in different plant species; Neth. J. Pl. Path. 89 (1983) 245-254.

3. Bol, J.F., H.J.M. Linthorst: Plant pathogenesis-related proteins induced by virus infection; Ann. Rev. Phytopathol. 28 (1990) 113-138.

4. Zaitlin, M., R. Hull: Plant virus-host interactions; Ann. Rev. Plant Physiol 38 (1987) 291-315.

5. Ryals, J., S. Uknes, E. Ward: Systemic aquired resistance; Plant Physiol. 104 (1994) 1109-1112.

6. Brederode, F.T., H.J.M. Linthorst, J.F. Bol: Differential induction of acquired resistance and PR gene expression in tobacco by virus infection, ethephon treatment, UV light and wounding; Plant Molec. Biol. 17 (1991) 1117-1125.

7. Vigers, A.J., S. Wiedemann, W.K. Roberts, M. Legrand, C.P. Selitrennikoff, B. Fritig: Thaumatin-like pathogenesis-related proteins are antifungal; Plant Science 83 (1992) 155-161.

8. Stinzi, A., T. Heitz, V. Prasa, S. Wiedemann-Merdinoglu. S. Kauffmann, P. Geoffroy, M. Legrand, B. Fritig: Plant pathogenesis-related proteins and their role in defense against pathogens; Biochem. 75 (1993) 687-706.

9. Mauch, F., L.A. Staehelin: Functional implications of the subcellular localization of ethylene-induced chitinase and $\beta$-1,3-glucanase in bean leaves; Plant Cell 1 (1989) 447-457.

10. Gianinazzi, S., C.Martin,J.C. Vallée: Hypersensibilité aux virus, températures et protéines solubles chez le Nicotiana Xanthi-nc. Apparition de nouvelles macromolécules lors de la répression de la synthèse virale; C. R. Acad. Sci. Paris (Serie D) 270 (1970) 23832386.

11. Van Loon, L.C., A. Van Kammen: Polyacrylamide disc electrophoresis of the soluble leaf proteins from Nicotiana tabacum L. var. 'Samsun' and 'Samsun NN'. II Changes in protein constitution after infection with tobacco mosaic virus; Virology 40 (1970) 199-211.

12. Van Loon, L.C., Y.A.M. Gerritsen, C.E. Ritter: Identification, purification, and characterization of pathogenesis-related proteins from virus-infected Samsun NN tobacco leaves; Plant Molec. Biol. 9 (1987) 593-609.

13. Van Loon, L.C.: Polyacrylamide disk electrophoresis of the soluble leaf proteins from Nicotiana tabacum L. var. 'Samsun' and 'Samsun NN; IV. Similarity of qualitative changes of specific proteins after infection with different viruses and their relationship to acquired resistance; Virology 67 (1975) 566-575. 
14. Kassanis, B., S. Gianinazzi, R.F. White: A possible explanation of the resistance of virus-infected tobacco plants to second infection; J. Gen. Virol. 23 (1974) 1116.

15. Carr, J.P., D.F. Klessig: The pathogenesis-related proteins of plants; in: Genetic engineering - Principles and methods, Vol. 11, edited by J.K. Setlow, Plenum Press, New York, 1989, pp. 65-109.

16. Cutt, J.R., D.F. Klessig: Pathogenesis-related proteins; in: Plant gene research - Genes involved in plant defense, edited by F. Meins Jr. and T. Boller, SpringerVerlag, Wien, New York, 1992, pp. 181-215.

17. Chessin, M.: Is there a plant interferon? Bot. Rev. 49 (1983) 1-28.

18. Van Loon, L.C.: The induction of pathogenesis-related proteins by pathogens and specific chemicals; Neth. J. Pl. Path. 89 (1983) 265-273.

19. Van Loon, L.C.: Mechanisms of resistance in virusinfected plants; in: The dynamics of host defense, edited by J.A. Bailey and B.J. Deverall, Academic Press Australia, Sydney, 1983, pp.123-190.

20. Röhring, C.: PR-Proteine (pathogenesis-related proteins) bei systemischen Virusinfektionen von Nicotiana spec; Thesis at University of Leipzig, Institute of Botany, Department of General Botany, 1996.

21. Clark, M.F., A.N. Adams: Characteristics of the microplate method of enzyme-linked immunosorbent assay for the detection of plant viruses; J. Gen. Virol. 34 (1977) 475-483.

22. Parent J.-G., A. Asselin: Detection of pathogenesisrelated proteins (PR or b) and other leaf proteins in the intercellular fluid of hypersensitive plants infected with tobacco mosaic virus; Can. J. Bot. 62 (1984) 564569.

23. Parent, J.-G., R. Hogue, A. Asselin: Glycoproteins, enzymatic activities, and $\mathrm{b}$ proteins in intercellular fluid extracts from hypersensitive Nicotiana species infected with tobacco mosaic virus; Can. J. Bot. 63 (1985) 928-931.

24. Davis, B.J.: Disc electrophoresis. II. Method and application to human serum proteins; Ann. N. Y. Acad. Sci. 121 (1964) 404-427.

25. Marcinka, K., C. Röhring, S. Kluge: Changes in protein patterns of pea plants systemically infected with red clover mottle virus; Biochem. Physiol. Pflanzen 188 (1992) 187-193.

26. Jamet, E., B. Fritig: Purification and characterization of 8 of the pathogenesis-related proteins in tobacco leaves reacting hypersensitively to tobacco mosaic virus; Plant Molec. Biol. 6 (1986) 69-80.

27. Hedrick, J.L., A.J. Smith: Size and charge of isomer separation and estimation of molecular weights of proteins by disk gel electrophoresis; Arch. Biochem. Biophys. 126 (1968) 155-164.
28. Meshi,T., Y.Okada: Systemic movement of viruses; in: Plant-microbe-interactions - Molecular and genetic perspectives; Vol. 2, edited by T. Koshuge and E.W. Nester, Macmillan Publishing Company, New York, 1987, pp. 285-304.

29. Leisner, S.M., R. Turgeon, S.H. Howell: Effects of host plant development and genetic determination on the long-distance movement of cauliflower mosaic virus in Arabidopsis; Plant Cell 5 (1993) 191-202.

30. Fortin, M.G., J.G. Parent, A. Asselin: Comparative study of two groups of $b$ proteins (pathogenesis related) from the intercellular fluid of Nicotiana leaf tissue infected by tobacco mosaic virus; Can. J. Bot. 63 (1985) 932-937.

31. Asselin, A., J. Grenier, F. Côté: Light-influenced extracellular accumulation of $b$ (pathogenesis-related) proteins in Nicotiana green tissue induce by various chemicals or prolonged floating on water; Can. J. Bot. 63 (1985) 1276-1283.

32. Edreva, A.M.: induction of 'pathogenesis-related' proteins in tobacco leaves by physiological (nonpathogenic) disorders; Exp. Bot. 41 (1990) 701-703.

33. Antoniw, J.F., R.F. White, D.J. Barbara, P. Jones, A. Longley: The detection of PR (b) proteins and TMV by ELISA in systemic and localized virus infections of tobacco; Plant Molec. Biol. 4 (1985) 55-60.

34. Yalpani, N., A.J. Enyedi, I. Raskin: Endogenous salicylic acid levels correlate with accumulation of pathogenesis-related proteins and virus resistance in tobacco; Phytopathology 83 (1993) 702-708.

35. Grüner, R., U.M. Pfitzner: The upstream region of the gene for the pathogenesis-related protein 1a from tobacco responds to environmental as well as to developmental signals in transgenic plants; Eur. J. Biochem. 220 (1994) 247-255.

36. Linthorst, H.J.M., R.L.J. Meuwissen, S. Kauffmann, J.F. Bol: Constitutive expression of pathogenesisrelated proteins PR-1, GRP, and PR-S in tobacco has no effect on virus infection; Plant Cell 1 (1989) 285291.

37. Cutt, J.R., M.H. Harpster, D.C. Dixon, J.P. Carr, P. Dunsmuir, D.F. Klessig: Disease response to tobacco mosaic virus in transgenic tobacco plant that constitutively express the pathogenesis-related PR1b gene; Virology 173 (1989) 89-97.

Address for correspondence:

Cornelia Röhring

Herrmann-Meyer-Str. 61

04207 Leiprig, Germany 